\title{
Cost Leadership Strategy: A New Game Strategy for Competitive Advantage in Milk Processing Firms in Kenya
}

\author{
Paul G. Kimiti \\ Stephen M. A. Muathe \\ Elishiba M. Murigi \\ School of Business, Kenyatta University, Kenya
}

Doi:10.19044/esj.2021.v17n23p296

Submitted: 01 May 2021

Accepted: 05 July 2021

Published: 31 July 2021
Copyright 2021 Author(s)

Under Creative Commons BY-NC-ND

4.0 OPEN ACCESS

Cite As:

Kimiti P.G., Muathe S.M.A. \& Murigi E.M. (2021). Cost Leadership Strategy: A New Game Strategy for Competitive Advantage in Milk Processing Firms in Kenya. European Scientific Journal, ESJ, 17(23), 296. https://doi.org/10.19044/esj.2021.v17n23p296

\section{Abstract}

Competitive advantage refers to the benefits that firms accrue from unique combination of possessions to outperform competitors. To build competitive advantage as a gateway to superior performance, firms pursue various beneficial strategic orientations. This study sought to establish whether cost leadership strategy gave rise to competitive advantage in milk processing firms in Kenya. The authors utilized the indicators of economies of scale, economies of scope and operational efficiency to operationalize cost leadership strategy while competitive advantage was operationalized through capabilities and knowledge. A census of all the milk processing firms was conducted with 148 respondents participating in the study. Data was collected using semi-structured self-administered questionnaires and subsequently analyzed using descriptive and inferential statistics. The study concluded that cost leadership strategy was a source of competitive advantage for the milk processors. It therefore recommends pursuit of cost leadership strategy as a competitive tool. It further recommends building of relevant capabilities and protection of tacit knowledge by firms as foundational blocks for competitive advantage.

Keywords: Cost Leadership Strategy, Competitive Advantage, Milk Processing Firms, RBV, Kenya 


\section{Introduction}

Milk processing firms have enormous nutritional and economic roles to both individuals and national economies. The firms produce essential commodities and significantly contribute to the well-being of populations globally (Spicka, 2015; Mwangi, Kabare \& Wanja, 2018; Kimiti, Muathe \& Murigi, 2020). Consequently, understanding the firms' competitiveness is crucial. However, the processors face enormous cost related performance challenges world over. In their study on dairy processing firms in the European Union, Gardebroek, Turi and Wijnands (2010) indicated that milk processors faced various cost challenges leading to poor performance due to low efficiency and small scale of operations.

Spicka (2015) on the other hand observed strong competition among corporate milk processors in Central Europe and noted that poor performance among the processors was attributed to low operational efficiency hence high costs. In Africa, a report by International Dairy Federation (2010) indicated that milk processors' performance was negatively affected by high costs of accessing credit. Ugandan Dairy Development Authority report (2013) observed that $98 \%$ of milk processing plants in the country operated below available capacities hence high business costs which had led to generally dismal performance in the industry. In Kenya, Chege and Bula (2015) noted collapse of some milk processors due to similar performance challenges. Low profit margins and declining milk uptake also characterize the Kenyan milk industry (Bebe, Rademaker, Lee, Kilelu \& Tonui, 2017; Chege \& Oloko, 2017; Kimiti et al., 2020).

Such situations necessitate firms to implement specific approaches to boost their performance levels (Barney, Ketchen \& Wright, 2011). The approaches adopted describe the strategic orientations that firms take to focus their operational efforts towards stated objectives (Elif \& Şengül, 2015). Strategies have been argued to be the most important possessions by firms (Kariuki, Awino \& Ogutu, 2011; Ndung'u, Otieno \& Rotich, 2016; Echwa \& Murigi, 2019). Competitive advantage on the other hand describes the gains theorized to originate from unique combination of critical firm possessions.

In reflecting on this, Lechner and Gudmundsson (2014) posited that a relationship exists between strategy, competitive advantage and superior firm performance. Cost leadership strategy is one of the strategies that has been widely studied and found to contribute to competitive advantage (Ismail, Rose, Uli \& Abdullah, 2012; Gorondutse \& Gawuna, 2017). Atikiya (2017) posited that cost leadership strategy generates competitiveness by allowing firms to create uniquely defendable positions.

Consequently, this study argued that cost leadership strategy could be the new game strategy for competitive advantage in milk processing firms in Kenya. The strategy addresses cost as a major performance challenge that 
firms face. While acknowledging previous research that suggests that cost leadership could indeed result in competitive advantage, this study notes that difference in context makes the findings ungeneralizable to the milk industry in Kenya.

To measure competitive advantage, the study adopted capabilities and knowledge as recommended in various studies (Kinyua, Muathe \& Kilika, 2015; Njoroge, Ongeti, Kinuu \& Kasomi, 2016; Salim, Rahman \& Abd Wahab, 2019). Cost leadership strategy on the other hand was operationalized using economies of scale, economies of scope and operational efficiency as adopted from Atikiya, Mukulu, Kihoro and Waiganjo (2015) and Kimiti et al. (2020).

The rest of the study is organized as follows. There is a section on review of theoretical and empirical literature, then a section on research methodology followed by a section on findings and discussions and finally a conclusions and recommendations section that also presents the study's limitations and future research.

\subsection{Review of Literature}

\subsection{Theoretical Review}

\subsubsection{Resource Based View}

Resource Based View (RBV) has its origins in the seminal works of Penrose (1959). The scholar posited that the level of firm performance was related to its resource possession. RBV value in choice of strategic orientation by firms lies in the proposition that superior performance results from differences in doing things (Armstrong \& Baron, 2004). Consequently, for a firm to attain competitive advantage in industry, it must employ its strategy in ways distinct from the competitors. Moreover, firms can only attain above average performance if they understand how internal resources, competitive advantage and performance relate (Rose, Abdullah \& Ismad, 2010). Here, resources represent the means by which strategy is formulated and implemented to build competitive advantage.

Creation of competitive advantage through implementation of cost leadership strategy also relies on the human resources that a firm possesses, their knowledge and their ability to grow the knowledge (Ormanidhi \& Stringa, 2008). Further sustainability of competitive advantage gained requires that firms constantly adjust to the state of competition. Consequently, the higher the degree of awareness a firm has about its competitive environment, the better placed it is to focus its strategic orientation towards achieving competitive edge over competitors. Thus, it is the resource possession defined by both quantity and quality that gives firms distinct identity and hence unique position in industry. 


\subsubsection{Dynamic Capability Theory}

The dynamic capability theory is an introduction of Stalk, Evans and Shulman (1992) with significant input from Teece and Pisano (1994). It advocates for building and constant renewal of resources and capabilities by firms to create competitive advantage (Harreld, O'Reilly \& Tushman, 2007; Muithya \& Muathe, 2020). These renewals are critical to the attainment of superior firm performance. Monsur and Yoshi (2012) noted that dynamic capabilities theory also logically extends Porter's generic competitive strategy.

It recognizes that the business environment is highly dynamic hence competitive advantage is characteristically transient. The theory recommends that firms regularly re-align with the competitive environment to sustain competitive advantage gained. The theory therefore calls for possession of relevant capabilities to constantly renew firm strategy in line with environmental dynamism (Teece, Pisano \& Shuen, 1997; Muithya \& Muathe, 2020). Capabilities represent abilities that enable firms to build competitive advantage and as a consequence transform strategy from theory into practice (Barney, 2001).

\subsection{Empirical Review}

Scholars have examined different strategic orientations and how they relate to competitive advantage and eventually firm performance (Muathe, 2002). Salavou and Halikias (2009) observed that it is not the strategies that firms pursue that directly lead to superior performance but the resultant competitive advantage that arises from such strategies. Monsur and Yoshi (2012) examined how vertical integration strategy, competitive advantage and firm performance interacted among apparel firms in Bangladesh. Vertical integration strategy was found to positively and significantly influence competitive advantage which subsequently significantly affected performance.

Talaja, Miocevic, Pavicic and Alfirevic (2017) sought to establish the relationship between market orientation, competitive advantage and performance of medium and large-sized firms in Croatia. It was concluded that market orientation led to competitive advantage that positively influenced performance. Sihite (2018) on the other hand assessed the role of diversification strategy in creating competitive advantage by Indonesian firms. The study concluded that diversification was positively correlated with competitive advantage and there was resultant improvement in performance. Wanjiru, Muathe and Kinyua-Njuguna (2019) examined whether corporate strategies gave rise to competitive advantage hence improving performance of manufacturing firms in Nairobi County. The authors concluded that the 
strategies led to competitive advantage that fortified firm strategic orientation relationships with performance.

Theoretically and empirically, the reviewed literature suggests that strategies are a crucial source of competitive advantage that in turn is key to superior firm performance. However, none of the reviewed empirical studies linked strategy and competitive advantage in the context of milk processing firms in Kenya. Further, while the studies give evidence on the role of strategy in firm competitiveness, they failed to address cost as a critical area where firms seek advantage in. This study therefore sought to bridge the existing gaps with the objective of establishing whether cost leadership strategy gave rise to competitive advantage in milk processing firms in Kenya. Consequently, the study hypothesized that:

Ho1 Cost leadership strategy significantly contributes to competitive advantage in milk processing firms in Kenya.

\subsection{Research Methodology}

The study was both descriptive and explanatory which facilitated integration of the positive characteristics of both designs as well as allowed triangulation of the results to boost validity (Creswell \& Creswell, 2017; Wanjiru et al., 2019). Descriptive component as argued by Muathe, (2010) and Muathe, Wawire and Ofafa (2013) was used to describe the phenomenon while the explanatory component was used to establish the cause-effect relationship between the two variables. The study's population consisted of all the 29 milk processors registered with Kenya Dairy Board (KDB) as at June 2019, 24 of which were small while 5 were large. 10 respondents were drawn from each large firm and 6 from each small firm hence a sample size of 194. The respondents were the manager and deputy of functional areas that either made decisions about costs, implemented cost reduction measures or managed cost performance in the firms. These were executive, operations, production, finance and marketing which were all in existence in the large firms while the small firms had at least three of the functional areas of interest. Data was collected using self-administered semi-structured questionnaires which were distributed by hand and by email. 148 usable questionnaires were obtained nationally. The data was subsequently analyzed using descriptive and inferential statistics. To test the study hypothesis $\mathrm{H}_{01}$, cost leadership strategy was regressed against competitive advantage using the following empirical model: 


$$
M=\beta_{0}+\beta_{1} \text { CLS + }
$$

Where; $\mathrm{M}=$ Competitive advantage

$\varepsilon=$ Error term

$$
\begin{gathered}
\text { CLS = Cost leadership strategy } \\
\beta_{\mathrm{i}}=\text { Beta Coefficient }
\end{gathered}
$$

\subsection{Findings and Discussions}

\subsection{Descriptive Statistics}

Sample mean and sample standard deviation were utilized to summarize measures on the characteristics of the sample. Tables 1 and 2 present the results of descriptive analysis for cost leadership strategy and competitive advantage respectively.

Table 1: Descriptive Statistics of Cost Leadership Strategy

\begin{tabular}{ccc}
\hline Variable & Mean & Standard Deviation \\
\hline Economies of Scale & 3.97 & 0.94 \\
\hline Economies of Scope & 3.75 & 0.99 \\
\hline Operational Efficiency & 4.33 & 0.74 \\
\hline Average & $\mathbf{4 . 0 2}$ & $\mathbf{0 . 8 9}$ \\
\hline
\end{tabular}

Source: Survey Data (2020)

Results in Table 1 show that the most widely adopted driver of cost leadership strategy was operational efficiency with a mean of 4.33 and standard deviation of 0.74 followed by economies of scale with a mean of 3.97 and standard deviation of 0.94 while the least adopted driver was economies of scope with a mean of 3.75 and standard deviation of 0.99 .

Table 2: Descriptive Statistics of Competitive Advantage

\begin{tabular}{ccc}
\hline Variable & Mean & Standard Deviation \\
\hline Capabilities & 4.38 & 0.68 \\
\hline Knowledge & 4.06 & 0.78 \\
\hline Average & $\mathbf{4 . 2 2}$ & $\mathbf{0 . 7 3}$ \\
\hline
\end{tabular}

Source: Survey Data (2020)

Results in Table 2 show that competitive advantage among milk processing firms was prevalently based on capabilities which had a mean of 4.38 and standard deviation of 0.68 . Knowledge on the other hand had a mean of 4.06 and standard deviation of 0.78 .

\subsection{Inferential Statistics}

Table 3 presents the results of regression analysis of cost leadership strategy on competitive advantage. 
Table 3: Cost Leadership Strategy Predicting Competitive Advantage

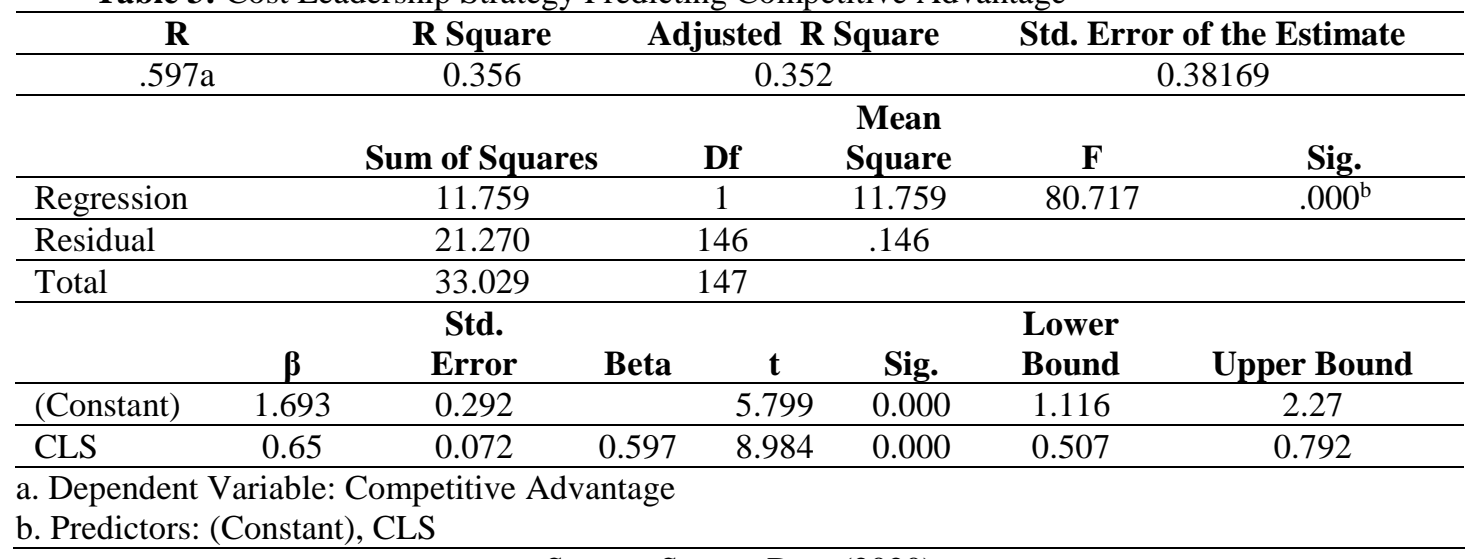

Source: Survey Data (2020)

The results in Table 3 show an adjusted R-square of 0.352 which signifies that cost leadership strategy accounted for $35.2 \%$ of the variation in competitive advantage. The results for ANOVA (F-statistics $=80.717$ $(\mathrm{p}=0.000)$ confirmed that cost leadership strategy significantly predicted competitive advantage since the model was significant. The results from regression analysis show that cost leadership strategy composite had a $\beta$ coefficient of 0.65 , p-value $=0.000$ meaning that cost leadership strategy had a positive and significant effect on competitive advantage in milk processing firms in Kenya. Additionally, the results illustrate that an increase in cost leadership strategy by one unit would result in an increase in competitive advantage by 0.65 units. From these findings, the study failed to reject $\mathrm{H}_{01}$ and concluded that cost leadership strategy significantly contributed to competitive advantage in milk processing firms in Kenya.

These findings are supported by postulates of the RBV that unique employment of strategy by firms contributes to being competitive in the industry. The importance of knowledge in creating a competitive edge has also been underscored by the findings as emphasized by RBV (Ormanidhi \& Stringa, 2008). Arguments by dynamic capability theory that firms need to constantly build and renew capabilities to create competitive advantage are also evident from these findings. The findings also corroborate Ismail et al. (2012) argument that operating at lower costs in comparison with competitors results in competitive advantage. The study findings further support conclusions by Monsur and Yoshi (2012), Talaja et al. (2017), Sihite (2018) and Wanjiru et al. (2019) which indicated that the strategies pursued by firms are an important source of competitive advantage. 


\subsection{Conclusions and Recommendations \\ 5.1 Conclusion}

The study sought to establish whether cost leadership strategy contributed to competitive advantage among milk processing firms in Kenya. This was important because the strategy addresses cost which has been shown to negatively affect performance of many firms. The study concluded that milk processors gained competitive advantage through implementation of cost leadership strategy. It was further concluded that cost leadership strategy significantly predicted competitive advantage and that the effect was positive. Advantages from cost leadership strategy arose from increasing the scale of operations, venturing into related business areas and improving operational processes through efficiency.

\subsection{Policy and Practical Recommendations}

Arising from the findings, the study recommends that milk processing pursue cost leadership strategy as a tool to gain competitive advantage in the milk industry. It further recommends that the firms build relevant capabilities to transform strategy from a merely theoretical statement into a practical tool for achieving superior performance. In addition, the firms must seek to protect tacit knowledge gained from operational experience through robust human resource management policies for workers' retention. Capabilities and tacit knowledge have been recognized as crucial foundational blocks for competitive advantage.

\subsection{Limitations and Future Research}

The study only considered firms registered with KDB as of June 2019. Inclusion of small home-based milk processors not registered with KDB is recommended in future studies to establish whether they pursue cost leadership strategy and if this results in competitive advantage. Cost leadership strategy was found to account for $35.2 \%$ of the variation in competitive advantage. Future studies should consider other factors besides cost leadership strategy that explain the remaining $64.8 \%$ of the variation in competitive advantage.

\section{References:}

1. Armstrong, M. \& Baron, A. (2004). Strategic HRM: The key to improved business performance. CIPD. London.

2. Atikiya, R. (2017). Effect of competitive strategies on the performance of manufacturing firms in Kenya. Journal of Business and Management Studies, 1(1), 1-13. 
3. Atikiya, R., Mukulu, E., Kihoro, J., \& Waiganjo, E. (2015). Effect of cost leadership strategy on the performance of manufacturing firms in Kenya. Journal of Management, 2(8), 134-143.

4. Barney, J. B., Ketchen Jr, D. J., \& Wright, M. (2011). The future of resource-based theory: revitalization or decline? Journal of Management, 37(5), 1299-1315.

5. Bebe, B. O., Rademaker, C. J., Lee, J., Kilelu, C. W., \& Tonui, C. (2017). Sustainable growth of the Kenyan dairy sector. Wageningen University and Research. Wageningen.

6. Chege, P. M., \& Bula, H. O. (2015). The effect of market forces on performance of dairy industries in Kenya. A case of Kenya Cooperative Creameries. Emergence, 7(35), 196-202.

7. Chege, P. M., \& Oloko, M. (2017). Influence of generic strategies on performance of large dairy firms in Kenya. European Journal of Business and Management, 9(30), 131-145.

8. Creswell, J. W., \& Creswell, J. D. (2017). Research design: Qualitative, quantitative, and mixed methods approaches. Sage Publications.

9. Echwa, M. \& Murigi, E.M. (2019). Strategic leadership and performance of domestic airline firms in Kenya. Eastern Africa Journal of Contemporary Research, 1(2), 144-152.

10. Elif, G. E. N. Ç., \& Şengül, R. (2015). A review on the relationship between strategic management and performance: The role of internal and external contexts. Strategic Public Management Journal, 1(2), 5671.

11. Gardebroek, C., Turi, K. N., \& Wijnands, J. H. (2010). Growth dynamics of dairy processing firms in the European Union. Agricultural Economics, 41(3-4), 285-291.

12. Gorondutse, A. H., \& Gawuna, M. S. (2017). Cost leadership strategy and performance of hotels in Nigerian context. Journal of Applied Structural Equation Modeling, 1(1), 1-12.

13. Harreld, J. B., O'Reilly III, C. A., \& Tushman, M. L. (2007). Dynamic capabilities at IBM: Driving strategy into action. California Management Review, 49(4), 21-43.

14. Kariuki, P. M., Awino, Z. B., \& Ogutu, M. (2011). Effect of firm level factors, firm strategy, business environment on firm performance. Business Environment Journal, 1(1)-27-32.

15. Kimiti, P. G., Muathe, S. M., \& Murigi, E. M. (2020). Gender of Respondents and Performance of Functional Areas of Milk Processing Firms in Kenya. International Journal of Economics, Commerce and Management, 8(9), 393-400. 
16. Kimiti, P. G., Muathe, S. M., \& Murigi, E. M. (2020). Nexus between cost leadership strategy and performance: Fact or fallacy in milk processing firms in Kenya. International Business Research, 13(10), $1-12$.

17. Kinyua, G. M., Muathe, S. M. A., \& Kilika, J. M. (2015). Effect of knowledge conversion and knowledge application on performance of commercial banks in Kenya. International Journal of Education and Research, 3(10), 431-445.

18. Kinyua, M. G., Muathe, S. M., \& Kilika, M. J. (2015). Influence of knowledge transfer and knowledge conversion on performance of commercial banks in Kenya. Science Journal of Business and Management. 3(6), 228-234.

19. Lechner, C., \& Gudmundsson, S. V. (2014). Entrepreneurial orientation, firm strategy and small firm performance. International Small Business Journal, 32(1), 36-60.

20. Monsur, S. M. T., \& Yoshi, T. (2012).Improvement of firm performance by achieving competitive advantages through vertical integration in the apparel industry of Bangladesh. Asian Economic and Financial Review, 2(6), 687-712.

21. Muathe, S.M., Wawire, N.W., \& Ofafa, G.A. (2013). An empirical study on the relationship between organizational factors and adoption of ICT among health related SMEs in Nairobi, Kenya. International Journal of Arts and Commerce, 2(3), 1-16.

22. Muathe, S.M.A. (2010). The determinants of adoption of information and communication technology by small and medium enterprises within the health sector in Nairobi, Kenya. Unpublished PhD thesis, Kenyatta University.

23. Muathe, SMA (2002). The application of information technology in enhancing customer satisfaction, a survey of soft drink companies in Nairobi [MBA Project, United States International University-Africa].

24. Muithya, V., \& Muathe, S. (2020). Dynamic capabilities and performance in the context of microfinance institutions in Kenya: An exploratory study. International Journal of Business, Economics and Management Works, 7(08), 15-29.

25. Mwangi, A. W., Kabare, N., \& Wanja, K. (2018). Influence of perceived service quality on consumer satisfaction amongst dairy milk processors in Kenya. International Journal of Research in Business and Social Science (2147-4478), 7(4), 44-57.

26. Ndung'u, C. M., Otieno, W., \& Rotich, G. (2016). Competitive business strategies on financial performance of commercial banks in Kenya: Case study of Equity Bank Limited. International Academic Journal of Economics and Finance, 2(1), 41-58. 
27. Njoroge, J. K., Ongeti, W. J., Kinuu, D., \& Kasomi, F. M. (2016). Does external environment influence organizational performance? The case of Kenyan State Corporations. Management and Organizational Studies, 3(3), 41-51.

28. Ormanidhi, O., \& Stringa, O. (2008). Porter's model of generic competitive strategies. Business Economics, 43(3), 55-64.

29. Penrose, E. T. (1959). The Theory of the Growth of the Firm. John Wiley. New York.

30. Rose, R. C., Abdullah, H., \& Ismad, A. I. (2010). A review on the relationship between organizational resources, competitive advantage and performance. Journal of International Social Research, 3(11), 488-498.

31. Salavou, H. E., \& Halikias, J. (2009). Strategy types of exporting firms: A view on the basis of competitive advantage. European Business Review, 21(2), 144-158.

32. Salim, N., Ab Rahman, M. N., \& Abd Wahab, D. (2019). A systematic literature review of internal capabilities for enhancing eco-innovation performance of manufacturing firms. Journal of Cleaner Production, 209, 1445-1460.

33. Sihite, M. (2018). Competitive advantage: Mediator of diversification and performance. In IOP Conference Series: Materials Science and Engineering, 288(1), 12-102.

34. Spicka, J. (2015). The Efficiency Improvement of Central European Corporate Milk Processors in 2008-2013. Agris On-Line Papers in Economics \& Informatics, 7(4).

35. Stalk, G., Evans, P., \& Shulman, L. E. (1992). Competing on capabilities: The new rules of corporate strategy. Harvard Business Review, 70(2), 57-69.

36. Talaja, A., Miocevic, D., Pavicic, J., \& Alfirevic, N. (2017). Market orientation, competitive advantage and business performance: Exploring the indirect effects. Društvenaistraživanja, 26(4), 583-604.

37. Teece, D., \& Pisano, G. (1994). The dynamic capabilities of firms: an introduction. Industrial and Corporate Change, 3(3), 537-556.

38. Teece, D.T., Pisano, G., \& Shuen, A. (1997). Dynamic capabilities and strategic management. Strategic Management Journal, 18(7), 509533.

39. Wanjiru, A. I., Muathe, S. M., \& Kinyua-Njuguna, J. W. (2019). Moderating effect of external operating environment on the relationship between corporate strategies and performance of manufacturing firms in Nairobi City County, Kenya. European Journal of Business and Management, 11(14), 34-44. 